\title{
Using a 3D hydrodynamic-biogeochemical model to compare estuarine nitrogen assimilation efficiency under anoxic and oxic conditions
}

\author{
$\underline{\text { L.C. Bruce }}^{a}$, P.L.M. Cook ${ }^{b}$ and M.R. Hipsey ${ }^{a, c}$ \\ ${ }^{a}$ School of Earth and Environment, The University of Western Australia, \\ 35 Stirling Highway, Crawley WA 6009, Australia. \\ Email: louise.bruce@uwa.edu.au \\ ${ }^{b}$ Water Studies Center, Monash University, VIC 3800, Australia \\ ${ }^{c}$ Centre for Ecohydrology, School of Environment Systems Engineering, The University of Western \\ Australia, 35 Stirling Hwy, Crawley WA 6009, Australia
}

\begin{abstract}
Estuarine ecosystems, an important interface between the land and the sea are valued for their high productivity as well as their potential to act as a sink for catchment-sourced nitrogen. The efficiency of nitrogen removal and storage in estuaries is dependent on a range of hydrodynamic and biogeochemical processes. In particular, the position of the freshwater/saltwater interface (commonly referred to as the 'salt wedge') and potential concurrent zone of oxygen deficiency in the benthic layer. The salt wedge in the Yarra River Estuary in Melbourne, Australia is both tidally and seasonally driven leading to transient patterns of hypoxia and anoxia causing dynamic shifts in nutrient recycling pathways. Understanding these dynamic nutrient cycles is considered of paramount importance as estuaries can act as major sinks for catchment nutrients that would otherwise end up in the ocean leading to nuisance algal blooms. Despite major implications for estuarine health, these extremely variant nitrogen cycling pathways in salt-wedge estuaries have rarely been quantified during anoxia and hypoxia. In this study we apply a coupled 3D curvilinear hydrodynamic-biogeochemical model to the Yarra River Estuary. Measured discharge, tidal and meteorological data were used to simulate the shifting zone of oxygen deficiency within the estuary over a period of 12 months from 1 July 2009 to 1 July 2010. Simulated concentrations of organic nitrogen, ammonium and nitrate and process rates of mineralisation, nitrification, denitrification and sediment fluxes were analysed in relation to upstream nutrient loads to select two distinct dates where estuarine nitrogen assimilation efficiency under anoxic and oxic conditions could be compared.
\end{abstract}

Simulated data from the anoxic period (10 January 2010) showed strong anoxia in the bottom waters. Warm air temperatures and low riverine discharge characterised forcing data. By contrast the forcing data for the oxic period (21 September 2011) was during an extended period of high flow so that simulated oxygen concentrations were close to saturation. Model results indicated a shift in denitrification from the sediments to the water column under anoxic conditions and a concomitant net flux of ammonium from the sediments to the water column. During the oxic period sediment denitrification dominated and ammonium flux out of the sediments was minimal. As a result net nitrogen assimilation capacity of the estuary stayed positive throughout the model domain. In contrast the model predicted negative net assimilation of nitrogen under anoxic conditions. Although the total denitrification efficiency for the estuary of both periods was positive, ( $8.9 \%$ and $7.3 \%$ for low and high flow periods respectively) the spatial distribution patterns were distinctly different.

The model has been used to highlight potential changes to the nitrogen dynamics in the estuary under altered catchment management practices. Rates of nitrification and denitrification in the sediments and shifts into the water column as well as fluxes of nitrogen across the sediment/water interface under anoxic/oxic conditions were analysed with respect to the nitrogen assimilation efficiency of the estuary. The results of these simulations demonstrate major implications for estuarine management in response to rapidly changing anthropogenic pressures.

Keywords: biogeochemistry, hydrodynamics, hydrology, estuary, numerical models, nitrogen cycle, denitrification efficiency, Yarra River Estuary 


\section{INTRODUCTION}

Estuarine ecosystems, an important interface between the land and the sea are valued for their high productivity as well as their potential to act as a sink of catchment-sourced nitrogen (Nixon et al. 1996, Seitzinger 1988). In a study of estuaries of the North Atlantic Ocean, Nixon et al. (1996) found they are able to retain and remove $30-65 \%$ of terrestrially derived nitrogen that would otherwise enter the coastal ocean. The efficiency of nitrogen removal and storage in estuaries is dependent on a range of hydrodynamic and biogeochemical processes. In particular, the position of the freshwater/saltwater interface (commonly referred to as the 'salt wedge') and potential concurrent zone of oxygen deficiency in the benthic layer. The location of the salt wedge within an estuary is highly dynamic, depending primarily upon the river discharge, river morphometry, tides and wind forcing. Under conditions of low river discharge, the residence time of the salt wedge within an estuary increases, potentially leading to the development of anoxia in the bottom waters (Ishikawa et al. 2004; Lin et al. 2006).

Since nitrogen can exist in both reduced and oxidised forms, the nitrogen cycle is sensitive to how patterns of oxygen are superimposed on the dynamic processes of transport and mixing. Organic nitrogen is mineralized to $\mathrm{NH}_{4}{ }^{+}$, converted under oxic conditions to $\mathrm{NO}_{3}$ by the process of nitrification, and then denitrified by a multi-step, microbially mediated, facultatively anaerobic process, where $\mathrm{NO}_{3}{ }^{-}$is reduced to $\mathrm{N}_{2}$ gas and ultimately lost to the atmosphere. When the water column is oxic, tight nitrification-denitrification coupling is associated with loss of nitrogen through denitrification processes within the sediments (An and Joye 2001; Henriksen et al. 1981; Jenkins and Kemp 1984). However, bottom water hypoxia creates an environment where elevated release of inorganic nitrogen from nutrient rich estuarine sediments has been observed (Cowan and Boynton 1996; Nowiki and Nixon 1985; Simon 1988). Under these conditions denitrification may take place within the water column (Brettar and Rheinheimer 1991; Hanning et al. 2007). This switch to water column denitrification may make a significant contribution to the denitrification efficiency of a salt wedge estuary. Whilst laboratory studies have reported denitrification in estuarine waters (Michotey and Bonin 1997, Omnes et al. 1996), the magnitude of this relative to sediment denitrification is not known. Further, the significance of the changing patterns of denitrification on the overall efficiency of nitrogen loss from salt wedge estuaries has yet to be quantified. Understanding the processes that control nitrogen storage and removal in estuaries that experience variable patterns of hypoxia/anoxia therefore remains of fundamental importance in effective management of coastal catchments.

The dominating influence of estuarine hydrodynamics on water column stratification, which in concert with organic carbon loading controls the oxygen content of the bottom water, means that any study attempting to predict and extrapolate the broader consequences anoxia on nitrogen cycling must have a strong concurrent focus on estuarine circulation processes and the factors that control them such as river flow. To this end, hydrodynamic models are an essential tool that can utilize routinely collected data on variables such as wind, river flow and tides to describe estuarine circulation. Hydrodynamic models are becoming increasingly sophisticated and are now routinely integrate biogeochemical and ecological processes (e.g. Bruce et al. 2006; Spillman et al. 2007), which allows a much more detailed understanding of the influences of physical forcing on biogeochemical process rates

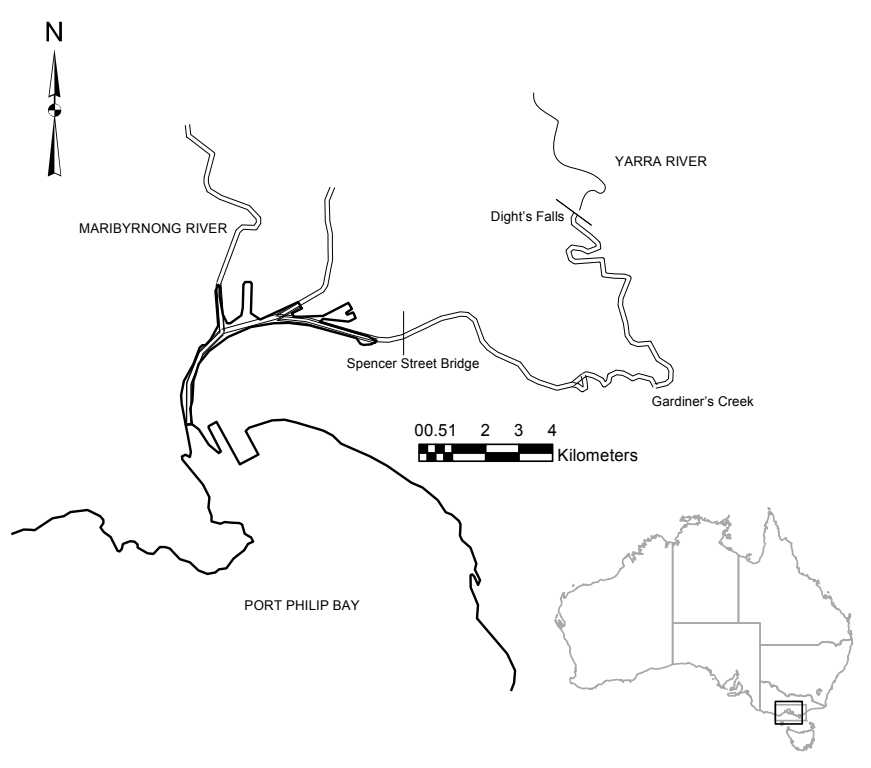

Figure 1 - Location of Yarra River Estuary

(Burchard et al. 2006; Bruce et al. 2008). Numerical models have been applied to estuarine environments that range in complexity from simple mass balance (Webster et al. 2005), incorporation of nutrient process representation (Robson et al. 2008; Valiela et al. 2004) to coupled 3-D hydrodynamic/biogeochemical models (Saetaert and Herman 1995; Xu and Hood 2006) in order to reproduce observed patterns of nitrogen and oxygen and provide insight into the processes responsible for these observed patterns 
The Yarra River Estuary in Victoria, Australia (Fig. 1) is an urban dynamic salt wedge estuary. The majority of nitrogen load entering the estuary at the upstream end is terrestrially derived. Previous work has estimated that the Yarra River Estuary contributes $15-20 \%$ of the total nitrogen load to the downstream Port Philip Bay (Harris et al. 1996) (Fig. 1). Of concern is that any increase in nitrogen loading from the estuary due to reduced denitrification rates could result in severe eutrophication of the bay with long-term degradation of ecological function (Harris et al. 1996). Understanding the key processes affecting nitrogen storage or removal in the Yarra River Estuary is therefore of paramount importance in order to quantify and effectively manage future nitrogen loads into Port Philip Bay.

The aims of this study were to a) compare the rates, pathways and net estuarine sources and sinks of nitrogen in the water column and sediments of the Yarra River estuary under periods of anoxia and oxia, and b) to assess how these rates are affected by changes in upstream nitrogen load. This was achieved through incorporation of a biogeochemical model of the nitrogen cycle within a three dimensional (3-D) hydrodynamic model suited to prediction of salt wedge dynamics in a riverine estuary with tight curvature. The model was used to quantify the impact of hypoxia and periodic anoxia on the overall nitrogen budget, and in particular to ascertain the nitrogen assimilation efficiency of the estuary under contrasting oxygen conditions.

\section{METHODS}

\subsection{Study Site}

The model domain selected for the Yarra River Estuary extends downstream from Spencer Street Bridge $\sim 14.5 \mathrm{kms}$ upstream to Dight's Falls (Figure 1) to cover the upstream extend of the salt wedge where anoixia is observed. The estuary is narrow (width from 30-120m generally wider, downstream narrowing upstream) and shallow (maximum depth $8 \mathrm{~m}$, minimum depth $1 \mathrm{~m}$ and average depth $4 \mathrm{~m}$ ). A sill underlying shallow water $(\sim 2 \mathrm{~m})$ has been observed approximately $7.5 \mathrm{~km}$ upstream of Spencer Street Bridge. Residence time as calculated by total volume over flow is estimated from 1 day to several weeks dependent on river discharge. For the study period 1 July 2009 to 1 July 2010, upstream flow (entering the model domain at Dight's Falls) ranged from minimum $2 \mathrm{~m}^{3} / \mathrm{s}$ (January-February) to maximum of $60 \quad \mathrm{~m}^{3} / \mathrm{s}$ (September-November) with an average flow of $8 \mathrm{~m}^{3} / \mathrm{s}$ (Figure 2a). A second inflow, Gardiner's Creek enters the Yarra Estuary approximately half way down the model domain (Figure 1). Flow from Gardiner's Creek is sporadic, correlated by local rainfall characterized by long periods of zero flow and short peaks of up to $50 \mathrm{~m}^{3} / \mathrm{s}$ (Figure 2a). The flow is driven downstream by a semi-diurnal tide, average tidal
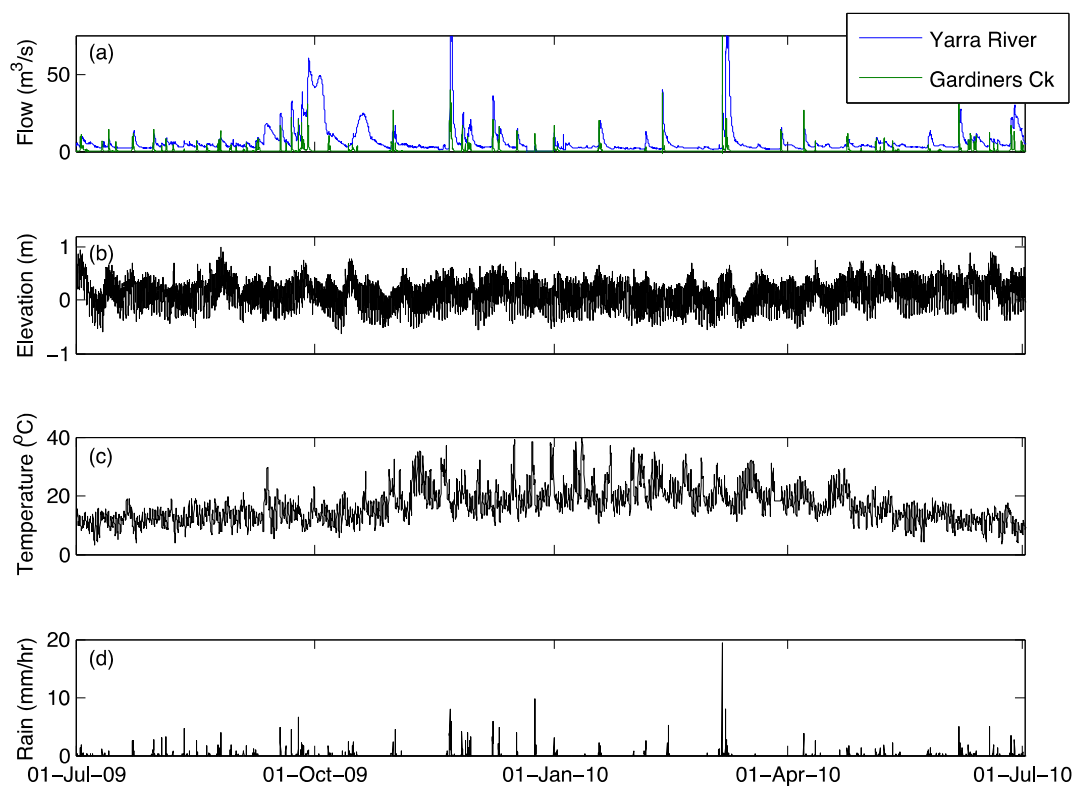

Figure 2 - Forcing input data for the GETM hydrodynamic driver. range $\sim 1.4 \mathrm{~m} \quad$ (Figure $2 \mathrm{~b}$ ).

Climate for Melbourne is temperate with warm summers (December-February) and cooler winters (JuneAugust), temperature ranges from $4-47^{\circ} \mathrm{C}$ (Figure 2c). Rain falls throughout the year with greatest fall from August to September (Figure 2d).

\subsection{Model Description}

The 3-D open-source General Estuarine Transport Model (GETM, www.getm.eu; Stips et al. 2004) is used in this study to simulate the hydrodynamics, mixing and transport of the Yarra River Estuary. This model has 


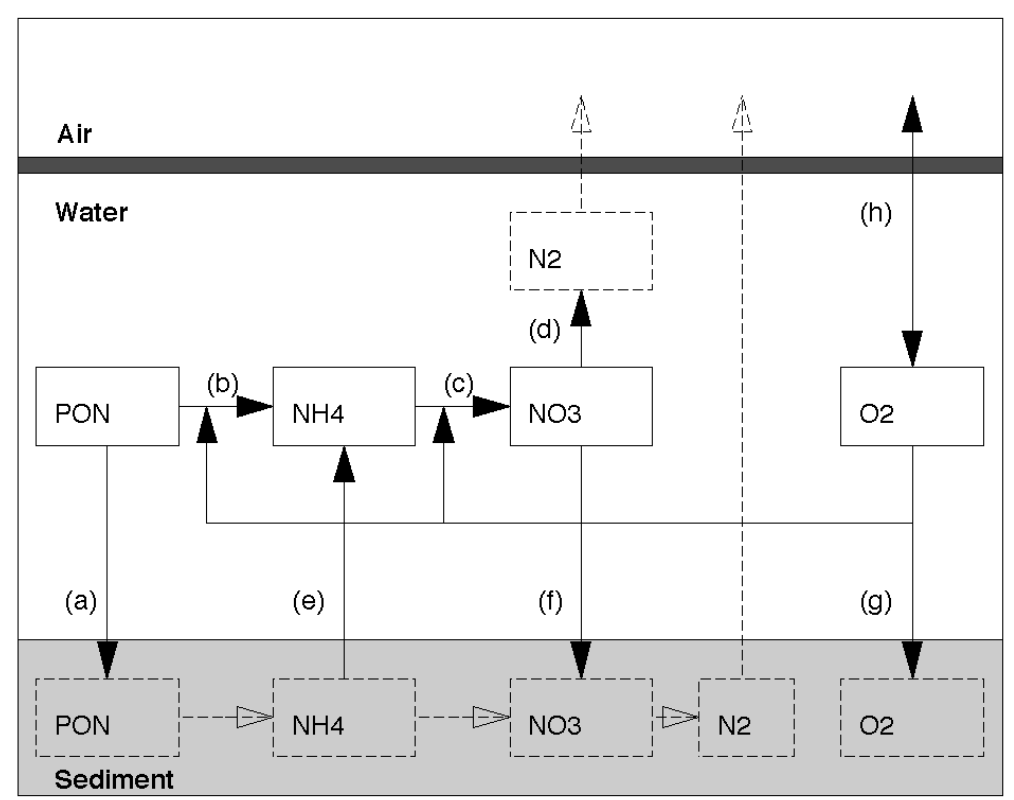

Figure 3 - Conceptual model of nitrogen state variables and fluxes in the AED biogeochemical model. Solid lines represent flux explicit to the model and dashed lines represent processes implicit to the model. Processes: (a) PON settling; (b) PON mineralisation; (c) nitrification; (d) denitrification; (e) $\mathrm{NH}_{4}$ sediment flux; (f) $\mathrm{NO}_{3}$ sediment flux; (g) $\mathrm{O}_{2}$ sediment flux; (h) $\mathrm{O}_{2}$ atmospheric exchange. been specifically designed to reproduce baroclinic, bathymetryguided flows in a tidally driven estuary (Burchard et al. 2004). The model includes high-order turbulence closure schemes to optimize realistic reproduction of vertical exchange processes. Numerical features implemented in GETM include curvilinear horizontal coordinates, high-order TVD advection schemes, stable flooding and drying algorithms and surface thermodynamics (Burchard et al. 2006). GETM has been applied to aquatic systems from lakes, estuaries (Burchard et al. 2004) to coastal seas (Stips et al. 2006).

The Aquatic Ecosystem Dynamics (AED) biogeochemical model has been implemented to simulate the nitrogen and oxygen in the estuary as part of a new open-source Framework of Aquatic Biogeochemical Models (FABM, fabm.sourceforge.net). FABM allows for a choice of modules that can be linked to a

hydrodynamic driver, in this case GETM. The full suite of AED models for the water column includes process representation of flow of carbon, nitrogen and phosphorus through the pelagic trophic food web from inorganic, dissolved and particulate organic, bacteria, multi-species phytoplankton, zooplankton and fish. AED also includes geochemistry modules able to resolve thermodynamic and kinetic reactions in the water and sediment of additional biogeochemical state variables. However, here we adopt a parsimonious approach and have configured the AED modules to only simulate particulate organic nitrogen; ammonium; nitrate and oxygen. The processes of mineralisation and sedimentation of particulate organic nitrogen, nitrification, denitrification, oxygen exchange through the surface water and sediment water and flux of ammonium and nitrate across the sediment/water interface are represented by the model (Figure 3). A full set of equations that describe these processes are provided in Bruce et al. (submitted).
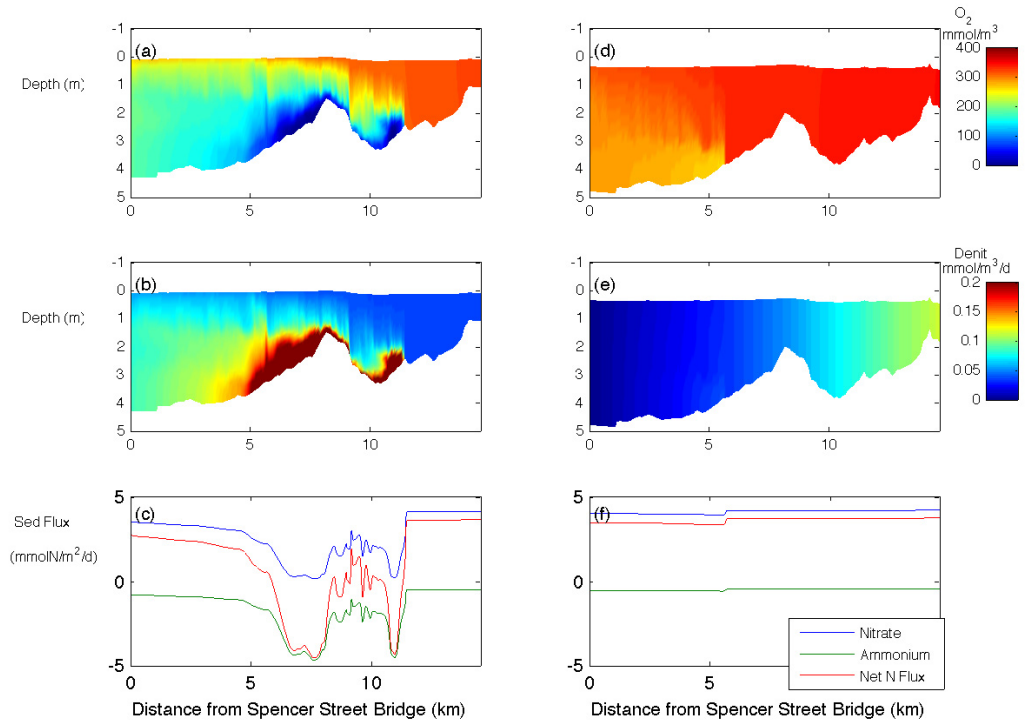

A curvilinear grid of 3 cells in the lateral and 400 cells in longitudinal and 20 depth averaged vertical layers was

Figure 4 - Simulated oxygen concentrations, rates of denitrification and sediment flux for the anoxic period (a-c) and oxic period (d-f). applied to the model domain. Smoothed interpolation of depth survey transects of the Yarra Estuary supplied 
by Melbourne Water were used to determine bathymetry. Gauged river discharge at Dight's Falls and Gardiner's creek every 5 mins were used to simulate flow rates while inflow concentration of state variables were averaged from weekly sampling. Surface water elevations taken every $5 \mathrm{mins}$ at the open boundary at Spencer Street Bridge were used to force the tidally driven flow for the open boundary. Monthly sampling data were linearly interpolated for salt, temperature and the biogeochemical state variables. Melbourne Water supplied inflow discharge and concentrations and elevation data. Monthly data for the biogeochemical state variables were supplied by Monash University. Parameters for the AED model (refer to Table 2, Bruce et al. submitted) were determined based on laboratory studies undertaken on sediment and water column samples along the model domain by Monash University.

\section{RESULTS AND DISCUSSION}

In order to contrast conditions of low and high oxygen, simulated concentrations of oxygen were plotted for 11 January 2010 (low flow, Figure 4a) and 21 September 2009 (high flow, Figure 4d).
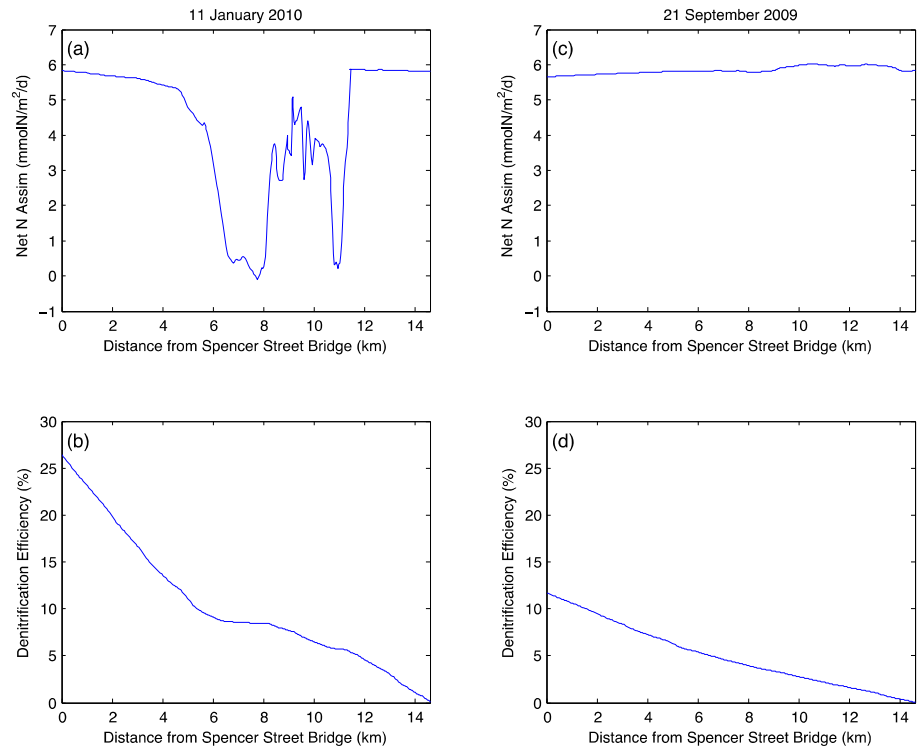

Figure 5 - Net nitrogen assimilation and denitrification efficiency for a period of anoxia (a-b) and oxia (c-d).

a consequence of increased residence time, the portion of hypoxic water column was significant throughout the middle reaches of the estuary (Figure 4a). The lowest oxygen concentrations were simulated either side of the sill as heavier salt water forced upstream by the tide, became trapped beneath the sill. As fresher upstream water pulsed downstream it caused persistent stratification sufficient to trigger extended hypoxic periods $\sim 6-8 \mathrm{~km}$ upstream of Spencer Street Bridge (Figure 4a). Similar to September 2009, the highest concentrations were simulated within the first $2.5 \mathrm{~km}$ of the upstream end since these areas are shallow and well-mixed with fresh oxygenated inflow waters.

Simulated rates of water column denitrification were strongly correlated with concentrations of oxygen (Figure $4 \mathrm{a} \& \mathrm{~b}$ ). High rates of denitrification were simulated in the water column during the period of anoxia but were negligible during the oxic period. By contrast when the water column was oxic sediment denitrification processes dominated and ammonium flux out of the sediments were negligible (Figure 4f). Under anoxic bottom waters, sediment denitrification was reduced and net nitrogen flux was positive across the sediment/water interface due to high rates of ammonium flux (Figure 4c).

To determine the net nitrogen assimilation capacity (in $\mathrm{mmol} \mathrm{N} / \mathrm{m}^{2} /$ day) of the estuary the following calculation was made,

$f_{\text {assim }}^{\mathrm{N}_{\mathrm{Net}}}=f_{\text {nitrif_wc }}^{\mathrm{NO}_{3}}+f_{\text {nitrif_sed }}^{\mathrm{NO}_{3}}+f_{\text {sed }}^{\mathrm{NO}_{3}}-f_{\text {sed }}^{\mathrm{NH}_{4}}$ 
Where $f_{\text {nitrif_wc }}^{\mathrm{NO}_{3}}$ and $f_{\text {nitrif_sed }}^{\mathrm{NO}_{3}}$ are the denitrification in the water column and sediment respectively, $f_{\text {sed }}^{\mathrm{NO}_{3}}$ the denitrification rate of the sediments and $f_{\text {sed }}^{\mathrm{NH}_{4}}$ the flux of ammonium from the sediments to the water column (all mmol N/m²/day).

These values were calculated for each cell in the domain for both the anoxic period (Figure 5a) and oxic period (Figure 5c). Net assimilation capacity was positive throughout the domain under oxic conditions and reached negative values under anoxia.

The cumulative denitrification efficiency was calculated to determine the potential sink or source of nitrogen in the estuary, defined as a percentage of total riverine nitrogen loads,

$E_{i}^{\text {denit }}=E_{i-1}^{\text {denit }}+\frac{\left(f_{\text {assim }}^{N_{N e}} * A_{i}\right)}{L_{T N}^{\text {river }}} * 100$

Where, $i$, is the cell numbered from the upstream boundary, $A_{i}$, the cell area $\left(\mathrm{m}^{2}\right)$ and $L_{T N}^{\text {river }}$ the total nitrogen loads from the river inflows (mmolN/day).

Net nitrogen assimilation for the Yarra Estuary was positive throughout the domain during the oxic period (Figure 5c). Conversely during the period of anoxia the model predicted a net source of nitrogen via ammonium flux in the deeper waters of the central estuary either side of the sill (Figure 5a). The model predicted a return to net nitrogen assimilation in the shallow waters overlying the sill. Cumulative denitrification efficiency (taking into account ammonium flux from the sediments) at the downstream end of the model domain was over double for the period of anoxia $(26.5 \%)$ compared to the high flow period $(11.7 \%)$ (Figure 5b\&d). The spatial distributions for both cases were also vastly different, the gradient for the summer month was much greater but plateaued in the central region, the high flow simulation had consistent gradient through out the domain. On 11 January 2010, the total nitrogen load into the estuary was estimated at $1.01 \mathrm{e}^{7} \mathrm{mmolN} /$ day and on 21 September $20092.93 \mathrm{e}^{7} \mathrm{mmolN} / \mathrm{day}$. The corresponding flows for these days were $2.07 \mathrm{~m}^{3} / \mathrm{s}$ and $6.34 \mathrm{~m}^{3} / \mathrm{s}$ respectively. Despite a threefold increase in flow and nitrogen load, the cumulative denitrification efficiency was not substantially lower in the September period of oxia. These results indicate that the denitrification efficiency of the estuary is strongly influenced by hypoxia, leading to a breakdown in the relationship expected between nitrogen retention and estuarine residence time (Nixon et al. 1996).

\section{CONCLUSIONS}

- Simulated patterns of oxygen concentrations in the Yarra River Estuary indicate a strong correlation with river discharge and thus residence time. Extensive anoxia was simulated during periods of low flow that was absent during periods of peak flow.

- Denitrification switched from the sediments to the water column under periods of simulated anoxia when ammonium flux from the sediments became significant.

- The model has been use to highlight potential changes to the nitrogen dynamics in the estuary under altered catchment management practices. The results of these simulations demonstrate major implications for estuarine management in response to rapidly changing anthropogenic pressures.

\section{ACKNOWLEDGMENTS}

This work was supported by Melbourne Water, Victorian Environment Protection Authority and the Australian Research Council (grant LP0991254). We thank Vera Folkman and Keryn Roberts for providing us with biogeochemical data from the Yarra Estuary. The global model development community responsible for the GETM and FABM numerical code used in this study. Technical support at the AED Group, UWA was supplied by Casper Boon and Brendan Busch.

\section{REFERENCES}

An S, Joye, SB (2001) Enhancement of coupled nitrification-denitrification by benthic photosynthesis in shallow estuarine sediments. Limnology and Oceanography, 46:62-74.

Brettar I, Rheinheimer G (1991) Denitrification in the Central Baltic: evidence for H,S-oxidation as motor of denitrification at the oxic-anoxic interface. Marine Ecological Progress Series, 77:157-169

Bruce LC, Hamilton DP, Imberger J, Gal G, Gophen M, Zohary T, Hambright KD (2006) A numerical simulation of the role of zooplankton in C, N and P cycling in Lake Kinneret, Israel. Ecol. Mod. 193:412436. 
Bruce LC, Jellison R, Imberger J, Melack J (2008) Effect of benthic boundary layer transport on the productivity of Mono Lake, California. Saline Systems, 4:11

Bruce LC, Cook PLM, Hipsey MR (submitted) Quantification of sediment and water processing of nitrogen in a periodically anoxic urban estuary using a 3-D hydrodynamic-biogeochemical model.

Burchard H, Bolding K, Villarreal MR (2004) Three-dimensional modelling of estuarine turbidity maxima in a tidal estuary. Ocean Dynamics, 54:250-265.

Burchard H, Bolding K, Kuhn W, Meister A, Nuemann T and Umlauf L (2006) Description of a flexible and extendable physical-biogeochemical model system for the water column. Journal of Marine Systems, 61:180-211

Cowan JLW, Walter RB (1996) Sediment-water oxygen and nutrient exchanges along the longitudinal axis of Chesapeake Bay: Seasonal patterns, controlling factors and ecological significance. Estuaries and Coasts, 19:562:580.

Grace MR, Jakob T, Donnert D, Beckett R (2003) Effect of an alternating oxic/anoxic regime on a (freshwater) Yarra River sediment. Australian Journal of Chemistry, 56:923-932

Hannig, M., G. Lavik, M. M. M. Kuypers, D. Woebken, W. Martens-Habbena, and K. Jürgens. 2007. Shift from denitrification to anammox after inflow events in the central Baltic Sea. Limnology \& Oceanography, 54: 1336-1345.

Harris G, Batley G, Fox D, Hakk D, Jernakoff P, Molloy R, Murray A, Newell B, Parslow J, Skyring G, Walker S (1996) Port Phillip Bay Environmental Study Report. CSIRO, Canberra.

Henriksen K, Hansen JI, Blackburn, TH (1981) Rates of nitrification, distribution of nitrifying bacteria, and nitrate fluxes in different types of sediment from Danish waters. Marine Biology, 61:299-304

Ishikawa T, Suzuki T and Qian X (2004) Hydraulic study of the onset of hypoxia in the Tone River Estuary. 130:551:561

Jenkins, M. C., and W. M. Kemp. 1984. The coupling of nitrification and denitrification in two estuarine sediments. Limnology and Oceanography, 29: 609-619.

Lin J, Xie L, Pietrafesa LJ, Shen J, Mallin MA, Durako MJ (2006) Dissolved oxygen stratification in two micro-tidal partially-mixed estuaries. Estuarine and Coastal Shelf Science, 70:423-437

Michotey V, and Bonin P (1997) Evidence of anaerobic bacterial processes in the water column: denitrification and dissimilatory nitrate ammonification in the northwestern Mediterranean Sea. Marine Ecological Progress Series, 160:47-56

Nixon SW, Ammerman JW, Atkinson LP, Berounsky VM, Billen G, Biocourt WC, Boynton WR, Church TM, Di Toro DM, Elmgren R, Garber JH, Giblin AE, Jahnke RA, Owens NJP, Pilson MEQ, Seitzinger SP (1996) The fate of nitrogen and phosphorus at the land-sea margin of the North Atlantic Ocean. Biogeochemistry 35:141-180

Nowiki B, Nixon SW (1985) Benthic nutrient remineralization in a coastal lagoon ecosystem. Estuaries 8:182-190

Omnes P, Slavyk G, Garcia N, Bonin P (1996) Evidence of denitrification and nitrate ammonification in the River Rhone plume (northwestern Mediterranean Sea). Marine Ecological Progress Series 141:275-281

Robson B, Bukaveckas PA, Hamilton DP (2008) Modelling and mass balance assessments of nutrient retention in a seasonally-flowing estuary (Swan River Estuary, Western Australia). Estuarine and Coastal Shelf Science, 76:282-292.

Seitzinger SP (1988) Denitrification in freshwater and coastal marine ecosystems: Ecological and geochemical significance. Limnol Oceanogr 33: 702-724

Simon NS (1988) Nitrogen cycling between sedimentand the shallow-water column in the transition zone of the Potomac River and Estuary: I. Nitrate and ammonium fluxes. Estuarine and Coastal Shelf Science, 26:483:497

Spillman CM, Imberger J, Hamilton DP, Hipsey MR, Romero JR (2007) Modelling the effects of Po River discharge, internal nutrient cycling and hydrodynamics on biogeochemistry of the Northern Adriatic Sea. Journal of Marine Systems, 68:167-200

Stips A, Bolding K, Pohlman T and Burchard, H (2004) Simulating the temporal and spatial dynamics of the North Sea using the new model GETM (General Estuarine Transport Model). Ocean Dynamics 54:266283.

Valiela I, Mazzilli S, Bowen JL, Kroeger KD, Cole ML, Tomasky G, Isaji T (2004) ELM, an estuarine nitrogen loading model: formulation and verification of predicted concentrations of dissolved inorganic nitrogen. Water Air Soil Pollut 157:365-391

Webster IT, Ford PW, Tillman P (2005) Estimating nutrient budgets in tropical estuaries subject to episodic flows. Marine Poll. Bull. 51:165-173

$\mathrm{Xu}$ J, Hood RR (2006) Modeling biogeochemical cycles in Chesapeake Bay with a coupled physicalbiological model. Estuarine and Coastal Shelf Science, 69:19-46 